\title{
Zastosowanie nanosekundowych impulsów laserowych do oceny naprężeń własnych cienkich warstw
}

\author{
The use of nanosecond laser pulses \\ to assess the residual stresses of thin films
}

\section{Streszczenie}

Przeprowadzono badania naprężeń własnych cienkich warstw metodą Laser Spallation Technnique - LST. Krótkie, nanosekundowe impulsy o dużej energii zostały zastosowane do wywołania delaminacji cienkich warstw a geometria odspojenia do oceny naprężeń własnych. Badania przeprowadzono dla miękkiej i plastycznej warstwy tytanu oraz twardej i kruchej warstwy TiN. Obie warstwy zostały nałożone metodą PVD na podłoże ze stali kwasoodpornej 304. Wartość naprężenia otrzymana metodą LST została zweryfikowana na podstawie badań metodą rentgenowską. Uzyskane wyniki badań wykazały, że krótkie impulsy laserowe o odpowiedniej energii mogą być stosowane do oceny naprężeń własnych w przypadku cienkich warstw o dużej wartości naprężeń ściskających.

Słowa kluczowe: naprężenia własne; cienkie warstwy; impuls laserowy

\begin{abstract}
The laser spallation technique was applied for measurement of residual stress of thin films. Two films of different properties, ductile and soft $\mathrm{Ti}$, and hard and brittle TiN, were studied. The films were produced on 304 steel substrate by PVD method. The residual stress value obtained by laser spallation technique LST were compared with stress value from X-ray diffraction method. Good agreement of stress values measured by both methods was attained. It was shown that shock wave induced by a nanosecond laser pulse adequately determines properties of PVD thin films on metal substrate.
\end{abstract}

Keywords: thin films; residual stress; laser pulse

\section{Wprowadzenie}

Impulsowe promieniowania laserowe o wysokiej gęstości energii, przy bardzo krótkim czasie ekspozycji impulsu $\left(10^{-8} \div 10^{-14}\right)$ w ciałach stałych łatwo generują fale uderzeniowe o bardzo wysokiej amplitudzie ciśnienia rzędu GPa. W latach dziewięćdziesiątych ubiegłego wieku rozpoczęto prace nad zastosowaniem promieniowania impulsowego dobadania wytrzymałości materiałów w warunkach udarowych Laser Spallation Technique LST [1], oceny adhezji cienkich warstw LASAT (ang. Laser Shock Adhesion Test) [2] czy umacniania laserowego powierzchni metali i stopów LSP - Laser Shot Peening [3,4]. Obróbka laserowa jest wykorzystywany do powierzchniowej obróbki umacniającej metali i stopów [5,6], a badania procesów związanych z tą obróbką prowadzone są w wielu ośrodkach krajowych i zagranicznych.

Rozwój nowych metod badań materiałów możliwy był dzięki zastosowaniu układu pomiarowego, w którym zastosowano warstwę inercyjną powodującą wzmocnienie amplitudy

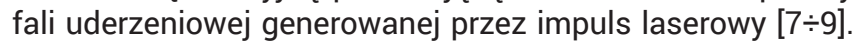
Impuls laserowy, poprzez przezroczystą dla promieniowania warstwę inercyjną (szkło kwarcowe, wodę), pada na warstwę absorpcyjną wywołując jej parowanie oraz tworzenie się plazmy. Na skutek gwałtownej ekspansji obłoku plazmy powstaje fala ciśnienia, która rozchodzi się w badanym materiale. Przy bardzo krótkich impulsach laserowych, rzędu ns, i odpowiednio dobranym rodzaju i grubości warstwy inercyjnej i absorpcyjnej efekty cieplne związane z oddziaływaniem wiązki z materiałem są pomijalne. Dzięki temu można rozpatrywać taki przypadek, jako czyste oddziaływanie mechaniczne fali ciśnienia z badanym materiałem [10]. Zastosowanie warstwy inercyjnej pozwala na wyeliminowanie rozpraszania fali naprężeń. W jej obecności występuje wzrost amplitudy impulsu ciśnienia, poprawa jego kształtu, krótszy czas narastania oraz lepsza powtarzalność tych cech. Zwiększa ona również prędkość procesu chłodzenia na granicy faz, co redukuje dyfuzję termiczną do badanego materiału [7]. Opracowany układ pomiarowy został wykorzystany w latach 90 . do badania adhezji cienkich warstw otrzymywanych metodą PVD, CVD [11\%13]. Fala naprężeń

Dr hab. inż. Joanna Radziejewska, prof. PW - Politechnika Warszawska.

Autor korespondencyjny/Corresponding author: jora@meil.pw.edu.pl 
generowana impulsem laserowym po przejściu przez podłoże wywołuje naprężenia rozciągające na granicy podłoże-warstwa, powodując delaminację warstwy. Wytrzymałość połączenia określana jest na podstawie pomiaru prędkości warstwy w momencie delaminacji. Dokładność metody zależy od precyzji pomiarów prędkości. Ze względu na bardzo krótkie czasy procesu rzędu kilkudziesięciu nanosekund, badania takie wymagają zaawansowanych technik pomiarowych interferometrów laserowych, dużej wiedzy i doświadczenia [14]. Metoda została zastosowana do oceny adhezji różnych warstw np.: TiN, hydroxyapatytu pokryć tlenkowych [15,16].

W oparciu o LASAT Ikedai współautorzy [17] zaproponowali metodę pomiaru naprężeń własnych $\mathrm{w}$ cienkich warstwach. W trakcie delaminacji warstwy o dużych wartościach ściskających naprężeń własnych występuje zmiana geometrii powierzchni. Wiele cienkich warstw otrzymywanych metodami PVD CVD ma ściskające naprężenia własne. Warstwa i podłoże są wykonane z materiałów o różnym współczynniku rozszerzalności cieplnej, przez co podczas chłodzenia w warstwie powstają naprężenia szczątkowe. Aby uwolnić te naprężenia, warstwa ma tendencję do separacji od podłoża i występuje pękanie na granicy faz. Na podstawie znajomości geometrii odspojenia i grubości warstwy możliwe jest obliczenie naprężeń własnych w warstwie. W zaproponowanej metodzie nie jest konieczna znajomość właściwości warstwy. W stosunku do najczęściej stosowanej rentgenowskiej metody pomiaru naprężeń własnych metodą tą możliwy jest pomiar naprężeń w warstwach o silnej teksturze czy o słabym stopniu krystalizacji. W takich przypadkach metoda XRD jest często zawodna.

W pracy przedstawiono wyniki eksperymentalne pomiaru naprężeń własnych cienkich warstw Ti i TiN wytworzonych metodą PVD. Krótkie, nanosekundowe impulsy o energii $0,3 \div 1,2 \mathrm{~J}$ zostały zastosowane do wywołania delaminacji warstw. Na podstawie geometrii odspojenia dokonano oceny wartości naprężeń własnych. Wartość naprężenia otrzymana metodą LST została zweryfikowana na podstawie badań metodą rentgenowską.

\section{Metoda pomiarowa}

Badania naprężeń własnych przeprowadzono dla warstw tytanu i azotku tytanu wytworzonych w firmie Surftec metodą PVD [18]. Podłoże stanowiła stal austenityczna 304. Próbki do badań miały średnicę $10 \mathrm{~mm}$. W celu osiągnięcia odpowiedniego poziomu naprężenia na granicy warstwa-podłoże powodującego delaminację zastosowano trzy grubości podłoża 0,5; 0,8 i $1 \mathrm{~mm}$. Przed testami zbadano grubość, chropowatość oraz mikrotwardość warstw.

Do badań wykorzystano laser Nd: YAGQuantel YG 981E o długości fali promieniowania 1,064 $\mu \mathrm{m}$ i czasie impulsu 10 ns. Zastosowano cztery wartości energii impulsu: 0,35; 0,$7 ; 1 ; 1,22 \mathrm{~J}$. Schemat układu pomiarowego przedstawiono na rysunku 1 . Impuls laserowy poprzez warstwę inercyjną (szkło) - 1, pada na warstwę absorpcyjną - 2, wywołując gwałtowne jej parowanie oraz tworzenie plazmy. Na skutek gwałtownej ekspansji obłoku plazmy powstaje fala ciśnienia, która rozchodzi się w podłożu - 3. Na granicy z warstwą - 4, powstaje fala naprężeń rozciągających powodujących delaminację.

Jako warstwy absorpcyjnej użyto grafitu o grubości $5 \mu \mathrm{m}$ a warstwę inercyjną stanowiło szkło o grubości $1 \mathrm{~mm}$. Przy bardzo krótkich impulsach laserowych, rzędu ns, i odpowiednio dobranym rodzaju i grubości warstwy absorpcyjnej efekty cieplne związane z oddziaływaniem impulsów laserowych z materiałem są pomijalnie małe.

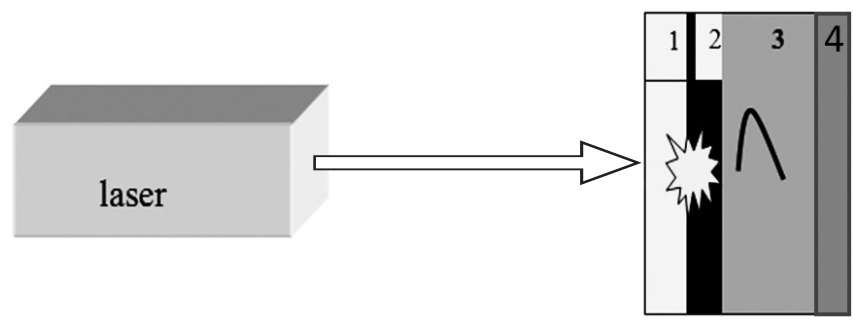

Rys. 1. Schemat stanowiska do badań materiałów impulsem laserowym: 1 - warstwa inercyjna, 2 - warstwa absorpcyjna, 3 - materiał, 4 - cienka warstwa

Fig. 1. Experimental scheme for material testing by laser pulse: 1 - inert layer, 2 - absorption layer, 3 - substrate, 4 - thin film

Odkształcenia powierzchni badanych materiałów mierzone były na mikroskopie konfokalnym Keyance Vk-X100, Wyznaczono średnicę odspojenia - d, jego wysokość - h. Pomiary chropowatości i grubości warstwy wykonano na profilometrze skaningowym. Mikrotwardość warstw została zmierzona metodą Vickersa przy obciążeniu $20 \mathrm{~g}$ na powierzchni.

\section{Wyniki badań}

\section{Właściwości warstw Ti i TiN}

Przeprowadzone badania struktury geometrycznej powierzchni wykazały stosunkowo wysoką chropowatość warstw PVD. Na rysunku 2 przedstawiono widok 3D oraz typowy profil chropowatości warstwy Ti. Wyznaczone parametry chropowatości wynosiły $R a=0,39 \mu \mathrm{m}, \mathrm{Rz}=3,14 \mu \mathrm{m}$ dla warstwy $\mathrm{Ti}$, dla warstwy TiN wysokości nierówności były niższe i wynosiły odpowiednio: $\mathrm{Ra}=0,26 \mu \mathrm{m}, \mathrm{Rz}=2,91 \mu \mathrm{m}$. Przyczyną występowania nierówności były krople materiału na powierzchni warstwy związane z procesem osadzania warstw metodą PVD.

Pomiary grubości warstw przeprowadzono na profilometrze oraz na zgładach metalograficznych na SEM. Stwierdzono, że grubość warstwy nie jest jednorodna, związane jest to głównie z wysokimi nierównościami na powierzchni. Grubość warstwy Ti wynosiła 3,4 $\pm 0,6 \mu \mathrm{m}$, dla warstwy TiN grubość oszacowano na 1,8 $\pm 0,3 \mu \mathrm{m}$.

Pomiary mikrotwardości metodą Vickersa wykazały, że twardość warstw jest zgodna z deklarowaną przez producenta. Mikrotwardość warstwy Ti wynosiła $640 \mathrm{HV}$ a warstwy TiN 2500 HV.

\section{Badania naprężeń własnych}

Próbki poddano oddziaływaniu impulsów laserowych, a następnie powierzchnie warstw Ti i TiN zostały zmierzone na profilometrze skaningowym. Badania wykazały, że minimalna energia niezbędna do wywołania delaminacji warstwy Ti wynosi 0,7 J, a dla warstwy TiN $1 \mathrm{~J}$. Przy niższych energiach impulsów laserowych i grubszym podłożu ciśnienie fali naprężenia granicy faz było zbyt niskie, aby wywołać odspojenie. W tablicy I przedstawiono energie impulsu i grubość podłoża, przy których przeprowadzono badania warstw. Wyniki wskazują na wyższą adhezję warstwy do podłoża w przypadku warstwy TiN.

$\mathrm{Na}$ rysunku 3 przedstawiono widok i profil powierzchni warstwy Ti po delaminacji przy energii impulsu 0,7 J. Wysokość odspojenia wynosi 1,4 $\mu \mathrm{m}$ i jest porównywalna z wysokościami nierówności powierzchni. Przy większych energiach impulsu uzyskano odpowiednio większą wysokość i średnicę obszaru odspojenia. Dla każdej wartości energii impulsu badania przeprowadzono trzykrotnie.

Na podstawie znajomości grubości warstwy t, wysokości h i promienia $r$ obszaru odspojenia, zakładając płaski stan naprężeń i korzystając rozwiązania zaproponowanego 
a)

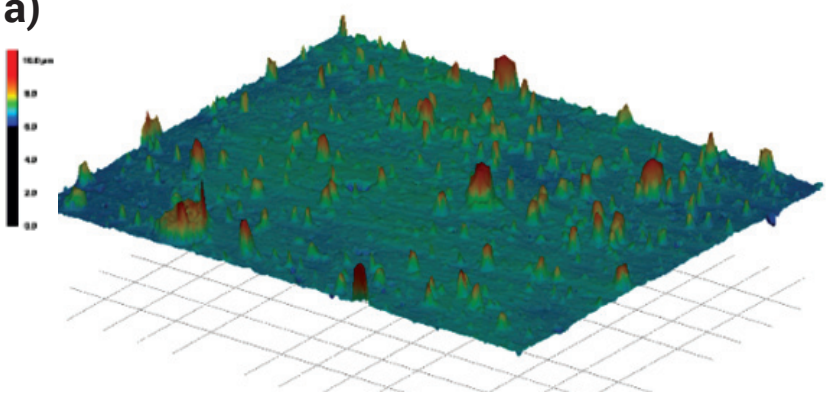

b)

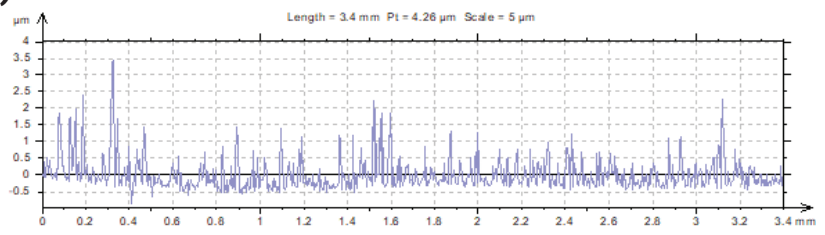

Rys. 2. Widok powierzchni 3D (a), profil chropowatości (b) warstwy Ti osadzonej metodą PVD

Fig. 2. 3D view (a) and profile (b) of Ti film deposited by PVD method

a)

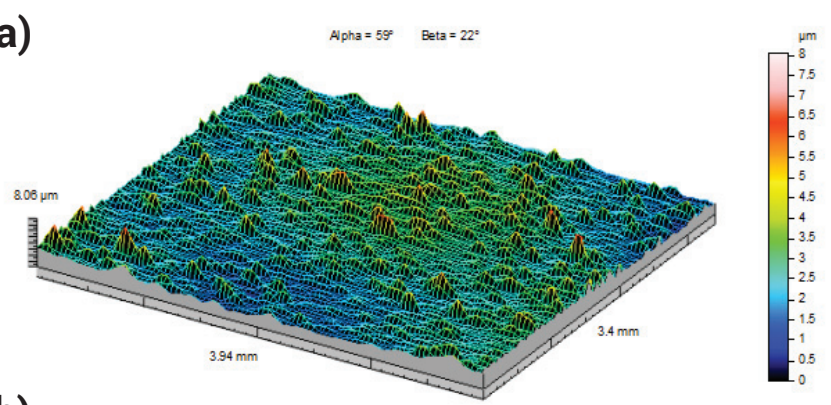

b)

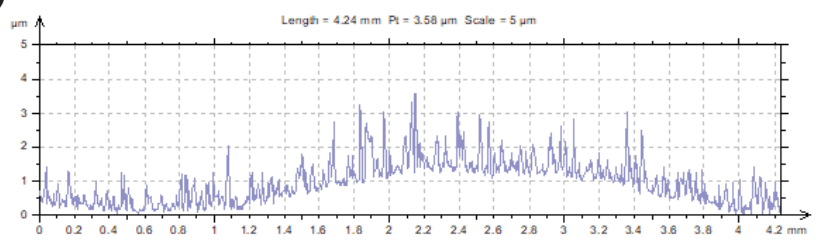

Rys. 3. Widok (a) i profil powierzchni po delaminacji (b) warstwy Ti, energia impulsu 0,7 J; profilometr skaningowy

Fig. 3. 3D view (a) and profile (b) after delamination of Ti film, pulse energy $0.7 \mathrm{~J}$; scanning profilometer

przez Ikeda [17] określono naprężenia własne w warstwie na podstawie zależności:

$\sigma=\left(\mathrm{pr}^{2}\right) / 6$ th ,

gdzie: $\mathrm{P}$ - ciśnienie atmosferyczne, $r$ - promień odspojenia, $\mathrm{h}$ - wysokość odspojenia, $\mathrm{t}$ - grubość warstwy.

W tablicy II przedstawiono wyniki pomiarów wielkości odspojenia dla różnych poziomów energii impulsu promieniowania oraz wyznaczone na podstawie równania 1 wartości naprężeń własnych w warstwie Ti.

Analogiczne badania przeprowadzono dla warstwy TiN, delaminacje warstwy uzyskano dla energii impulsu 1,2 i 1,25. Przy energii impulsu $1,2 \mathrm{~J}$ wysokość obszaru wynosiła $\mathrm{h}=3,1 \mu \mathrm{m}$ a promień odspojenia $\mathrm{r}=1,3 \mathrm{~mm}$. W tablicy III przedstawiono wyniki pomiarów wielkości odspojenia oraz wyznaczone wartości naprężeń własnych. Średnia wartość naprężeń własnych wynosiła 6,3 $\pm 0,6 \mathrm{GPa}$.

Wyniki badań zostały zweryfikowane na podstawie pomiarów naprężeń własnych metodą rentgenowską. Badania dyfrakcyjne wykazały silną teksturę dla obu warstw, co znacznie ograniczało wiarygodność uzyskanych wyników. W przypadku warstwy Ti do obliczeń przyjęto następujące dane: $\mathrm{E}=110 \mathrm{GPa}, \mathrm{v}=0,36$ [19]. Wartość naprężeń własnych wynosiła $\sigma=-0,86 \mathrm{GPa}, \Delta \sigma \pm 0,07 \mathrm{GPa}$. Dla warstwy TiN
Tablica I. Parametry eksperymentu delaminacji warstw Ti i TiN przy zastosowaniu impulsu laserowego

Table I. Laser pulse energy and substrate thickness applied for delamination test for Ti and TiN films

\begin{tabular}{|c|c|c|c|c|}
\hline \multirow{2}{*}{ warstwa } & \multirow{2}{*}{ E [J] } & \multicolumn{3}{|c|}{ Grubość podłoża [mm] } \\
\cline { 3 - 5 } & & $\mathbf{0 , 5}$ & $\mathbf{0 , 7}$ & $\mathbf{1 , 0}$ \\
\hline \multirow{3}{*}{$\mathrm{Ti}$} & 0,5 & brak & brak & brak \\
\cline { 2 - 5 } & 0,7 & występuje & brak & brak \\
\cline { 2 - 5 } & 1,0 & występuje & występuje & brak \\
\cline { 2 - 5 } & 1,2 & występuje & występuje & brak \\
\hline \multirow{2}{*}{ TiN } & 1,0 & występuje & brak & brak \\
\cline { 2 - 5 } & 1,2 & występuje & występuje & brak \\
\hline
\end{tabular}

Tablica II. Energia impulsu, wysokość - h, promień - r odspojenia oraz wyznaczone wartości naprężeń własnych warstwy Ti na podłożu ze stali 304

Table II. Laser pulse energy, height $-\mathrm{h}$ and radius $-\mathrm{r}$ of the delamination as well as determined residual stress for Ti filmon 304 steel substrate

\begin{tabular}{|c|c|c|c|}
\hline $\mathbf{E}[\mathbf{J}]$ & $\mathbf{h}[\mathbf{m m}]$ & $\mathbf{r}[\mathbf{m m}]$ & $\begin{array}{c}\text { Naprężenia własne } \\
\text { [GPa] }\end{array}$ \\
\hline 0,7 & 0,0026 & 0,78 & 1,15 \\
\hline 0,7 & 0,0032 & 0,84 & 1,07 \\
\hline 0,7 & 0,0026 & 0,76 & 1,09 \\
\hline 1 & 0,0026 & 0,82 & 1,17 \\
\hline 1 & 0,0132 & 1,36 & 0,69 \\
\hline 1 & 0,0127 & 1,34 & 0,7 \\
\hline 1,2 & 0,0013 & 1,99 & 1,36 \\
\hline 1,2 & 0,0037 & 1,11 & 1,51 \\
\hline 1,2 & 0,0049 & 0,96 & 0,93 \\
\hline 1,25 & 0,0062 & 1,1 & 0,95 \\
\hline 1,25 & 0,0125 & 1,5 & 0,92 \\
\hline 1,25 & 0,006 & 1,03 & 0,86 \\
\hline $\begin{array}{c}\text { Wartość } \\
\text { średnia }\end{array}$ & - & - & 1,01 \\
\hline
\end{tabular}

Tablica III. Energia impulsu, wysokość - h, promień - r odspojenia oraz wyznaczone wartości naprężeń własnych warstwy Ti na podłożu ze stali 304

Table III. Laser pulse energy, height $-\mathrm{h}$ and radius $-\mathrm{r}$ of the delamination as well as determined residual stress for Ti filmon 304 steel substrate

\begin{tabular}{|c|c|c|c|}
\hline $\mathbf{E}[\mathbf{J}]$ & $\mathbf{h}[\mathbf{m m}]$ & $\mathbf{r}[\mathbf{m m}]$ & $\begin{array}{c}\text { Naprężenia własne } \\
{[\mathbf{G P a}]}\end{array}$ \\
\hline 1,2 & 0,0032 & 1,21 & 4,9 \\
\hline 1,2 & 0,0033 & 1,25 & 8,6 \\
\hline 1,2 & 0,0029 & 1,38 & 6,4 \\
\hline 1,25 & 0,0062 & 1,85 & 5,0 \\
\hline 1,25 & 0,0051 & 1,84 & 6,2 \\
\hline 1,25 & 0,0015 & 1,15 & 6,7 \\
\hline $\begin{array}{c}\text { Wartość } \\
\text { średnia }\end{array}$ & - & - & 6,3 \\
\hline
\end{tabular}


przyjęto: $\mathrm{E}=250 \mathrm{GPa}, \mathrm{v}=0,20$. Wartość naprężeń wynosiła $\sigma=-7,2 \mathrm{GPa}, \Delta \sigma \pm 1,7 \mathrm{GPa}$. Wartość naprężeń własnych wyznaczonych obiema metodami jest zbliżona, również różnice wartości dla obu warstw są porównywalne.

Wyznaczona proponowaną metodą LST wartość naprężeń ściskających w warstwie TiN -6,3 GPa jest porównywalna do wartości naprężeń -8 GPa dla warstwy naniesionej metodą PVD o zbliżonej grubości wyznaczonych metodą XRD uzyskanych w pracy [15]. Niższe wartości -5 GPa stwierdzono $w$ przypadku warstwy TiN o grubości $5 \mu \mathrm{m}$ na podłożu stalowym [20]. Dla warstwy Ti wyznaczona wartość naprężeń jest analogiczna jak wartość naprężeń -1 GPa wyznaczonej w pracy [21]. Zatem otrzymane wyniki naprężeń własnych wyznaczone metodą LST i XRD są wiarygodne.

Stosunkowo duży błąd pomiarowy, który występuje w proponowanej nowej metodzie pomiarowej, związany jest z trudnością precyzyjnego pomiaru średnicy odspojenia. W przypadku dużej wysokości chropowatości granica pomiędzy obszarem odspojonym a nieodspojonym jest nieostra. Ponadto grubość badanych warstw była niejednorodna, co wpływało na rozrzut wyników.

\section{Wnioski}

- Otrzymane wyniki naprężeń własnych nową metodą z wykorzystaniem nanosekundowych impulsów laserowych cienkich warstw Ti oraz TiN osadzanych metodą PVD są zgodne z wartościami wyznaczonymi metodą rentgenowską.

- W warstwie Ti stwierdzono naprężenia ściskające, wartość wyznaczona metodą LST wynosiła -1 GPa a metodą XRD $\sigma=-0,86 \mathrm{GPa}$. Dla warstw TiN wartość naprężeń własnych wyznaczona obiema metodami wynosiła -6,3 GPa; a XRD $\sigma=-7,2 \mathrm{GPa}$.

- Proponowana metoda pomiaru z wykorzystaniem nanosekundowych impulsów laserowych LST może z powodzeniem być stosowana do wyznaczania dużych wartości ściskających naprężeń własnych w cienkich warstwach technologicznych o różnych właściwościach, o silnej teksturze, bez konieczności znajomości właściwości mechanicznych warstw.

\section{Literatura}

[1] Gupta V., Argon A.S., Parks D.M., Cornie J.A.: Measurement of interface strength by a laser spallation technique, J. Mech. Phys., Solids 40, 1992, pp. 141-147.

[2] Vossen L.: Adhesion Measurement of Thin Films, Thick Films and Bulk Coatings, ASTM STP640, 1978, pp. 122-133

[3] Montross Ch.S., Wei T., Ye T., Clark G., Mai Y-W.: Laser shock processing and its effect on microstructure and properties of metal alloys; a review, Int. J. of Fatique 24, 2002, pp. 1021-1036.

[4] Napadłek W., Sarzyński A.: Umacnianie warstwy wierzchnie stopu tytanu WT1-3 falą uderzeniową generowaną impulsem laserowym-zjawiska fizyczne i wybrane właściwości, Inżynieria Materiałowa 3, 2007, s. 228-232.

[5] Radziejewska J., Kalita W.: Badanie wpływu parametrów obróbki hybrydowej na mikrostrukturę warstw wierzchniej, Przegląd Spawalnictwa Vol. 81, Nr 10, 2009, s. 20-26.

[6] Radziejewska J.: Stan warstwy wierzchniej po laserowej oraz laserowomechanicznej modyfikacji powierzchni, Przegląd Spawalnictwa, Vol. 88, $\mathrm{Nr} 3,2016$, s. 9-13.

[7] Berthe R., Fabbro R., Peyre P., Tollier L., Bartnicki E.: Shock waves from a water confined laser-generated plasma, J. Appl. Phys. 82, 1997, pp. 2826-2832.

[8] Oros C.: Investigations involving of shock wave generations and shock pressure measurement in direct ablation regime and confined ablation regime, Shock waves 11, 2002, pp. 393-397.

[9] Berthe R., Fabbro R., Peyre P., Bartnicki E.: Wavelength dependent of laser shock-wave generation in the water-confinement regime, J. Appl. Phys., 85 , No. 11, 1999, pp. 7552-7555.

[10] Radziejewska J.: Application of a nanosecond laser pulse to evaluate dynamic hardness under ultra-high strain rate, Optics and Laser Technology, 78, 2016, pp. 125-133.
[11] Wang J., Weaver R.L., Sottos N.R.: A parametric study of laser induced thin film spallation, Experimental Mechanics 42 (1), 2002, pp. 74-83.

[12] Tang C., Zhu J.: The measurement of interface strength of TiN coating/substrate by laser spallation, Int. J. Refract. Hard Metals 14, 1996, pp. 203-206.

[13] Youtsos A.G., Kiriakopoulos M., Timke T.: Experimental and theoretical/ numerical investigations of thin films bonding strength, Theoretical and Applied fracture Mechanics 31, 1999, pp. 47-59.

[14] Yuan J., Gupta V.: Measurement of interface strength by the modified laser spallation technique. I. Experiment and simulation of the spallation process, J. Appl. Phys. 74, 1993, pp. 2388-2396.

[15] Zhang L., Yang H., Pang X., Gao K., Volinsky A.A.: Microstructure, residual stress, and fracture of sputtered TiN films, Surface \& Coatings Technology 224, 2013, pp. 120-125.

[16] Bégué G., Fabre G., Guipont V., Jeandin M., Bilhe P., Guédou J.Y., Lepoutre F.: Laser Shock Adhesion Test (LASAT) of EB-PVD TBCs: Towards an industrial application, Surface and Coatings Technology, 237, 2013, pp. 305-312.

[17] Ikeda R., Uchiyama T., Cho H., Ogawa T., Takemoto M.: An advanced method for measuring the residual stress of deposited film utilizing laser spallation technique. Science and Technology of Advanced Materials 7, 2006, pp. 90-96

[18] http://www.surftec.pl/firma/powlekanie-pvd/

[19] http://asm.matweb.com/search/SpecificMaterial.asp?bassnum=mq304a

[20] Leoni M., Scardi P., Rossi S., Fedrizzi L., Massiani Y.: (Ti,Cr)N and Ti/TiN PVD coatings on 304 stainless steel substrates: Texture and residual stress, Thin Solid Films, 345, 2, 1999, pp. 263-269.

[21] Carvalho N.J.M., Zoestbergen E., Kooi B.J., De Hosson J.Th.M.: Stress analysis and microstructure of PVD monolayer TiN and multilayer TiNy(Ti,Al)N coatings, Thin Solid Films 429, 2003, pp. 179-189. 